\title{
DEVONIAN DIKE SWARMS OF ALKALINE, CARBONATITIC AND PRIMITIVE MAGMA-TYPE ROCKS FROM THE SOUTH KOLA PENINSULA: GEOCHEMICAL AND ISOTOPIC CONSTRAINTS ON PLUME- LITHOSPHERIC INTERACTION
}

\author{
Ivan Mahotkin ${ }^{1}$, Hilary Downes ${ }^{2}$, Ernst Hegner ${ }^{3}$, Andy Beard ${ }^{2}$ \\ ${ }^{1}$ De Beers, Russia; ${ }^{2}$ School of Earth Sciences, Birkbeck University of London, UK; ${ }^{3}$ University of Munich, Germany
}

\section{INTRODUCTION}

Geochemistry and $\mathrm{Sr}-\mathrm{Nd}-\mathrm{Pb}$ isotopic compositions of two dike swarms within the Devonian magmatic area of the south Kola peninsula (NW Russia) have been studied. One swarm is located in the north-west part of the Kandalaksha gulf (Niva, Kandaguba areas) and the other occurs further east on Turiy Cape. The NivaKandaguba dike swarm also includes numerous dikes on islands in the Kandalaksha gulf and a kimberlite dike exposed on Krestovaya mountain (Beard et al., 1996; Beard et al., 1998). Both swarms of Devonian dikes are situated within the Belomorian Belt of Late Archaean crust which experienced Early Proterozoic extension at 2.4-2.5 B.a. and collision process at 1.9-2.0 B.a. (Bibikova et al., 1996; Balagansky et al., 1998). To the south-east along the suture zone between the Belomorian Belt and the Kola craton, several fields of Devonian melnoites and diamondiferous kimberlites occur in the Terskiy Bereg area of the Kola Peninsula, in the Onega peninsula and Zimniy Bereg area of the Arkhangelsk region (Kalinkin et al., 1993, Mahotkin, et al. 1997; Mahotkin et al., 2000; Beard et al., 2000).

\section{GEOLOGY SETTING}

The south Kola Devonian dike magmatism was related to local extension during regional uplift of the KolaArkhangelsk region (Mahotkin et al., 2000). Extension formed two stages of dike magmatism in the south Kola peninsula in both Early and Late Devonian times i.e. 378-395 M.a. and 360-368 M.a (Bulakh \& Ivannikov, 1984; Ivannikov \& Ruchlov, 1996; Beard et al., 1996 Claesson et al. 2000). The Early Devonian magmatism comprises dikes of alnoites, aillikites and potassic carbonatites in the Niva area and Kandalaksha gulf. The Late Devonian magmatism comprises dikes of Group 1 kimberlites, melilite picrites, alkaline picrites, damkjernites, sodalite-bearing ultra-Na carbonatites of the Niva area, calcite-bearing nephelinites and sodium carbonatites of the Kandaguba, melilitites, melanonephelinites and sodium carbonatites of Turiy Cape.

\section{GEOCHEMISTRY}

The Early Devonian dikes and single Upper Devonian Group 1 kimberlite are classified as part of the ultra-K and $\mathrm{K}$ rock series, whereas the Late Devonian dikes are $\mathrm{K}-\mathrm{Na}$ and ultra-Na rock series (Figure 1).

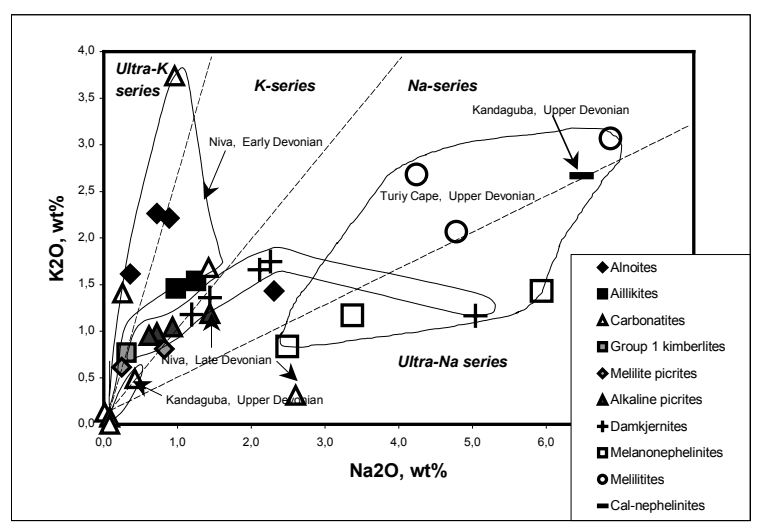

Figure 1: $\mathrm{K}_{2} \mathrm{O}(\mathrm{wt} \%)$ vs $\mathrm{Na}_{2} \mathrm{O}(\mathrm{wt} \%)$ for the Early and Late Devonian dikes of the Kola peninsula.

The picrites, damkjernites, melilitites and nephelinites form several distinctive clusters on the $\mathrm{CaO}+\mathrm{Na}_{2} \mathrm{O}+\mathrm{K}_{2} \mathrm{O}$ vs $\mathrm{SiO}_{2}+\mathrm{Al}_{2} \mathrm{O}_{3}$ plot (Figure 2)

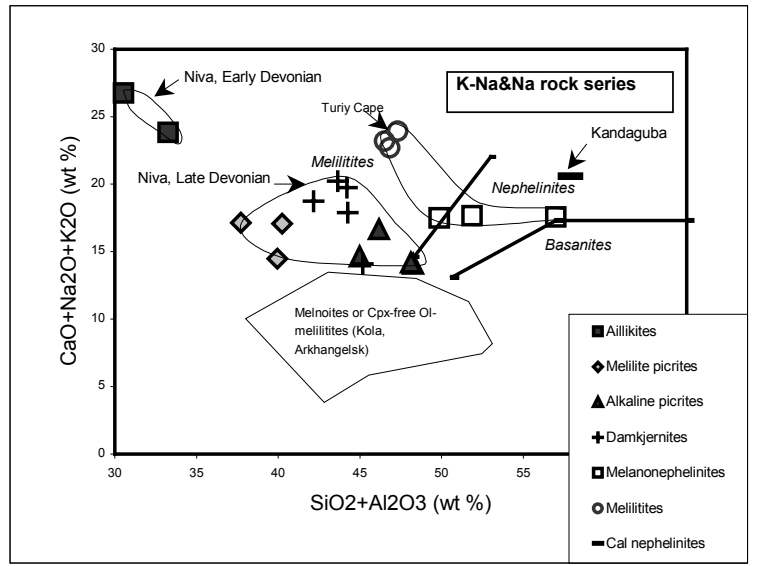

Figure 2: $\mathrm{CaO}+\mathrm{Na}_{2} \mathrm{O}+\mathrm{K}_{2} \mathrm{O}$ vs $\mathrm{SiO}_{2}+\mathrm{Al}_{2} \mathrm{O}_{3}(\mathrm{wt} \%)$ for the $\mathrm{K}-$ $\mathrm{Na}$ and $\mathrm{Na}$ rock series of the Kola peninsula. 
proposed by Le Bas (1989). Damkjernites and alkaline picrites have small chemical overlap and both rock types plot in the melilitite field.

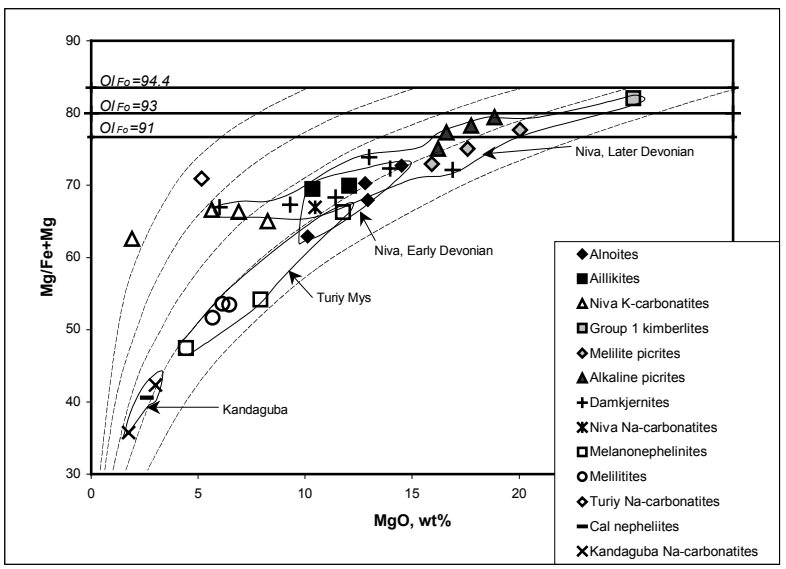

Figure 3: Plot of $100 * \mathrm{Mg} /(\mathrm{Mg}+\mathrm{Fe})$ vs $\mathrm{MgO}$ for the Kola Devonian dikes and its fields. The thick horizontal solid lines are mg-number of melts which are equilibrium with olivine composition $\mathrm{FO}_{94.4}, \mathrm{Fo}_{93}$ and $\mathrm{Fo}_{91}$ under $\mathrm{Kd}=0.29$. Dashed line curves show Mg-numbers of the evolved melts from which different portions of $\mathrm{Fo}_{94.4}$ olivine were fractionated.

Evolution of the Devonian Kola dike melts has been estimated from Mg-number (Figure 3) and $\mathrm{Ni}$ abundances. The evolution curves of $\mathrm{Mg}$-number shown in Figure 3 were calculated for $K_{d}=0.29$ and for different starting compositions. These plots show that Late Devonian alkaline picrites and melilite picrites from the Niva area are primitive melts derived from mantle peridotites characterised by $\mathrm{FO}_{92-93}$. Both rock groups plot on slightly different olivine fractionation curves suggesting that their primary melts are slightly different. The Group 1 kimberlites are primitive melts derived from mantle peridotites also characterised by $\mathrm{Fo}_{92-93}$ or were derived from more depleted mantle peridotites characterized by $\mathrm{Fo}_{94}$ However, they have also accumulated olivine $\mathrm{Fo}_{92}$ (Beard et al., 1998). Ni abundances (550-1050 ppm) in these rocks are very high and typical for primitive magmas (Figure 4). The Early Devonian alnoites and aillikites and Late Devonian damkjernites from the Niva have mgnumbers of 63-72 and high Ni contents (150-500 ppm). They are slightly evolved as a result of fractionation of olivine $\mathrm{Fo}_{91-92}$ from primary melts with 16-18 wt\% $\mathrm{MgO}$. The Late Devonian melanophelinites and melilitites from Turiy Cape are moderately evolved magmas and have low-moderate $\mathrm{Ni}$ abundances (50200 ppm). The Late Devonian calcite nephelinites from Kandaguba are strongly evolved magmas with very low Ni contents (34 ppm).
Trace element patterns of the average compositions of each group of south Kola Devonian dikes (except carbonatites) are shown on normalised multi-element plots in comparison with average ocean island basalts (OIB) and of low-Ti Devonian melnoites of the Arkhangelsk region (Figure $3 \mathrm{~A}, \mathrm{~B}, \mathrm{C}$ ). The latter were derived from ancient mantle sources with $\mathrm{TDM}_{\mathrm{Nd}}=2.1$ 2.3 B.a. (Mahotkin et al, 1997) and reflect chemical heterogeneity in the subcontinental lithospheric mantle (BB SCLM) of the Belomorian belt prior to Devonian

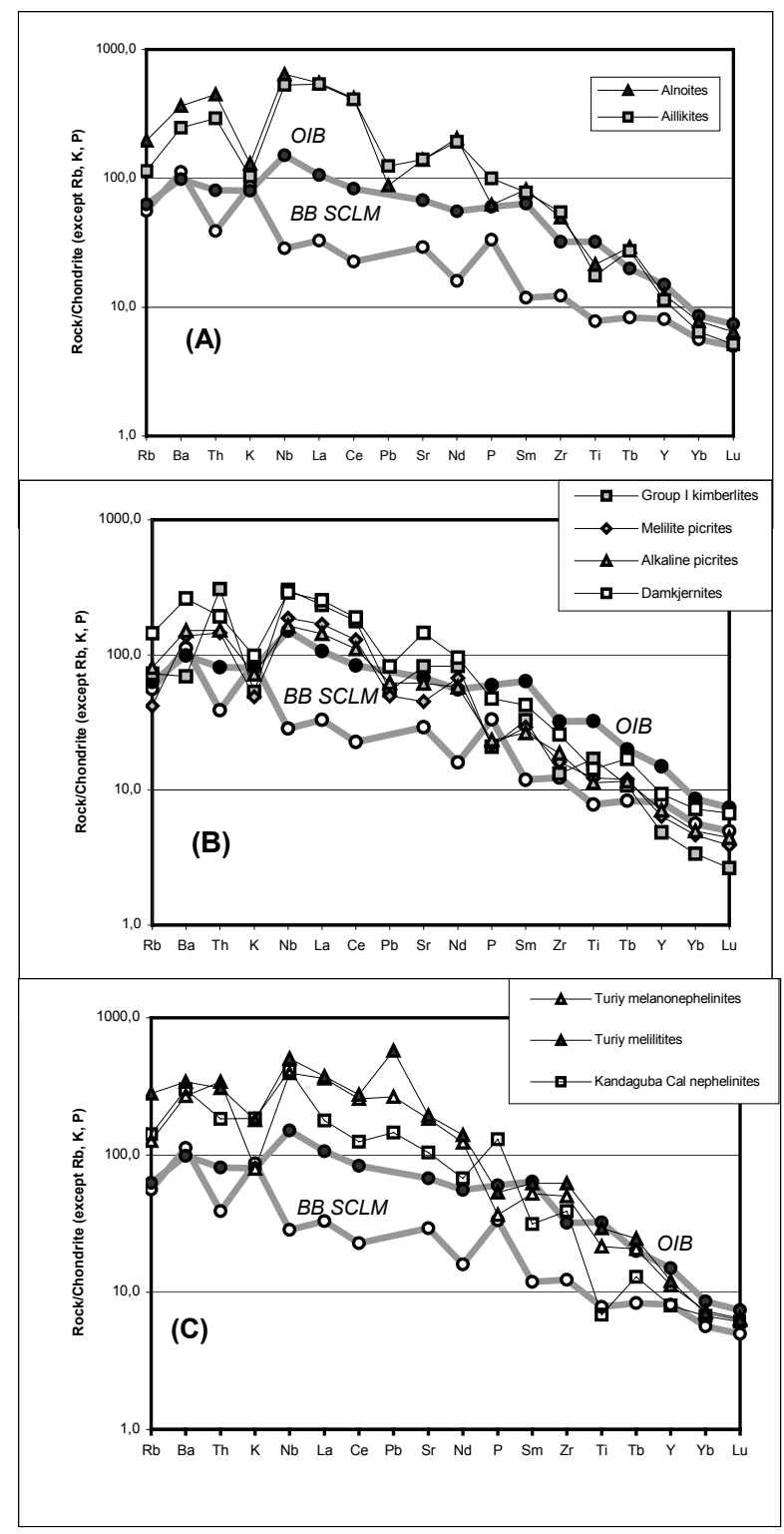

Figure 4 (A, B, C). Trace elements patterns for Early Devonian alnoites and aillikites from Niva (A); Late Devonian kimberlites, melilite picrites, alkaline picrites and damkjernites from Niva (B); Late Devonian melanonephelinites from Turiy and Late Devonian cal nephelinites from Kandaguba (C). 
magmatic activity. The Niva dikes of the both K-and $\mathrm{Na}$ - rock series are enriched in LREE, Th, $\mathrm{Nb}, \mathrm{Ba}, \mathrm{Sr}$ and to some extent in $\mathrm{Rb}$ relative to OIB and they show distinct negative $\mathrm{K}$ and $\mathrm{Pb}$ anomalies. Patterns for Late Devonian Turiy and Kandaguba melilitites and nephelinites differ from those of the Niva rocks in having a positive $\mathrm{Pb}$ anomaly and a small negative $\mathrm{K}$ anomaly. Generally inter-element variations $(\mathrm{Ba} / \mathrm{Nb}$, $\mathrm{La} / \mathrm{Ba}$ and others) and patterns of the south Kola rocks are similar to those of OIB and are strongly different from melts derived from the SCLM beneath the Belomorian belt (BB SCLM).

Trace element variations in primitive and slightly evolved members of the south Kola dike swarms were used to estimate the degree of melting and mantle source mineralogy. These variations indicate that all dike rocks were derived from a phlogopite-bearing garnet lherzolite mantle source. Low degrees of melting of this source $(0.7-3 \%)$ influenced the preservation of phlogopite in the restitic mineral assemblage, giving rise to K-troughs on the chondrite-normalised trace element patterns of the dike rocks. A comparison of Early and Late Devonian melting conditions indicates an increase in the proportions of melts (up to 3-5\%) in Late Devonian times and an increase in the depth of melting in the mantle that resulted in the generation of kimberlite magma.

\section{ISOTOPE COMPOSITIONS}

$\mathrm{Sr}-\mathrm{Nd}$ isotope composition of south Kola dikes are shown in $\varepsilon_{\mathrm{Sr}}-\varepsilon_{\mathrm{Nd}}$ plots (Figure $5 \mathrm{~A}, \mathrm{~B}$ ). Early Devonian Niva alnoites, aillikites and $\mathrm{K}$ carbonatites were derived from a single mantle source which was slightly depleted in radiogenic $\mathrm{Sr}$ and $\mathrm{Nd}\left(\varepsilon_{\mathrm{Nd}} \sim+4\right)$. This mantle source was isotopically similar to the depleted OIB source and was enriched in trace elements shortly before magmatism, consistent with the presence of phlogopite in that source. The Late Devonian Niva rocks are subdivided into two isotopic groups: (1) rocks with $\varepsilon_{\mathrm{Nd}} \sim+4$ and low radiogenic $\mathrm{Sr}$, the mantle source of which is similar to the OIB source (Group I kimberlite and melilite picrites, which are isotopically identical, and $\mathrm{Na}$ carbonatite depleted in radiogenic $\mathrm{Sr}$ ), (2) damkjernites and alkaline picrites with $\varepsilon_{\mathrm{Nd}} \sim 0$ and very variable radiogenic $\mathrm{Sr}$ that indicates some contamination by old material with variable $\mathrm{Rb} / \mathrm{Sr}$ ratio and negative $\varepsilon_{\mathrm{Nd}}$. The Late Devonian Turiy dikes are derived from a slightly depleted OIB type mantle source. Isotopic composition of the Terskiy pipes is similar to the latter group. The BB SCLM with Early Proterozoic $\mathrm{TDM}_{\mathrm{Nd}}$ model age did not contribute to the $\mathrm{Nd}$ isotopic variation of the south Kola dike magmatism, in contrast to the Devonian kimberlitemelnoite magmatism of the Arkhangelsk region. Only Late Devonian Kandaguba rocks show slight enrichment in radiogenic source that could be the influence of EM-1 mantle source.

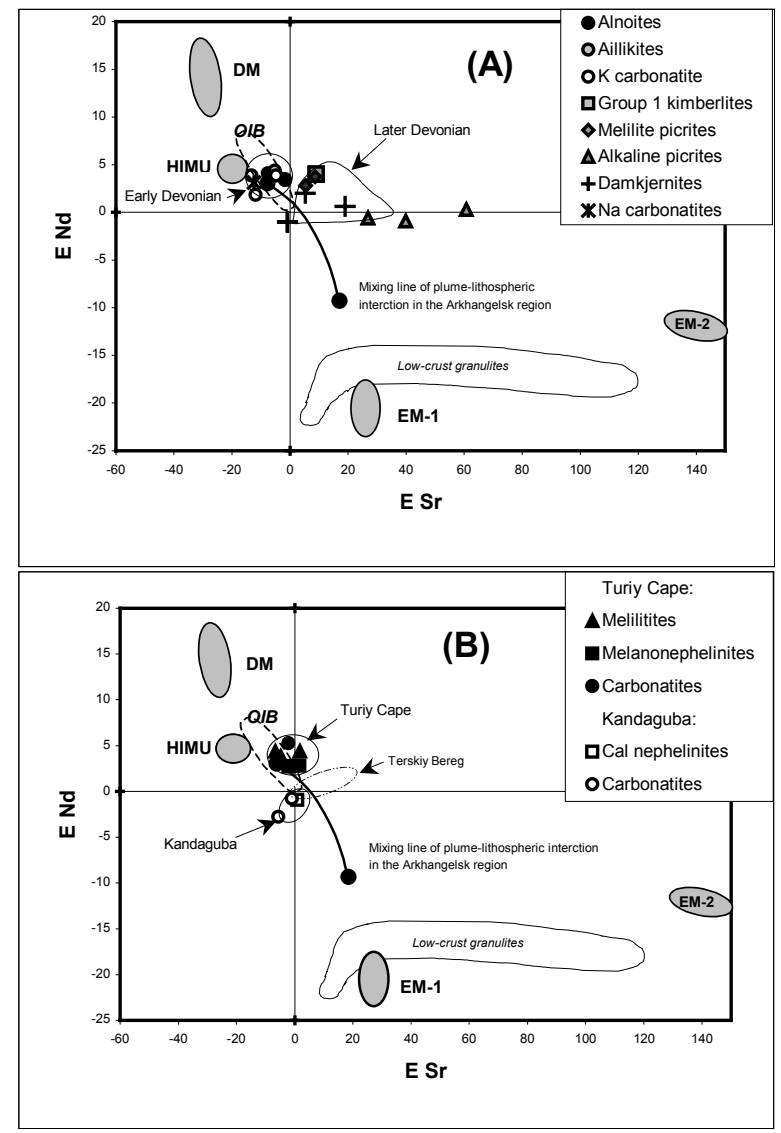

Figure 5 (A, B). Sr-Nd isotope diagram of the Early and Late Devonian Niva rocks (A); Late Devonian Turiy and Kandaguba rocks in comparison with isotope values of mantle reservoirs (DM, HIMU, DM1, DM2), Devonian Terskiy pipes, Arkhangelsk pipes and low crust granulite xenoliths from Devonian pipe of Eloviy island of the Kandalaksha gulf.

Present day $\mathrm{Pb}$-isotope ratios of the south Kola dikes are shown in Figure 6. All of the dikes are enriched in radiogenic $\mathrm{Pb}$ and plot to right of the Geochron. The Early and Late Devonian Niva dikes (with $\varepsilon_{\mathrm{Nd}} \sim+4$ ) form a good correlation giving an apparent age of 1.75 B.a. that is interpreted as age of forming HIMU component in the south Kola. Two other $\mathrm{Pb}-\mathrm{Pb}$ correlations are produce by the damkjernites with an apparent age of 3.0 B.a. and alkaline picrites with an apparent age of 1.4-1.3 B.a. that could be interpreted as contamination of mantle source regions by lower crust material (with low $\mu$ and Archaean $\mathrm{Pb}$ model age) and probably a subcontinental lithospheric mantle (SCLM*) material (with low $\mu$, Middle Proterozoic $\mathrm{Pb}$ model 
age). All these $\mathrm{Pb}-\mathrm{Pb}$ positive correlations are for rocks with negative $\mathrm{Pb}$ anomalies on trace element patterns.
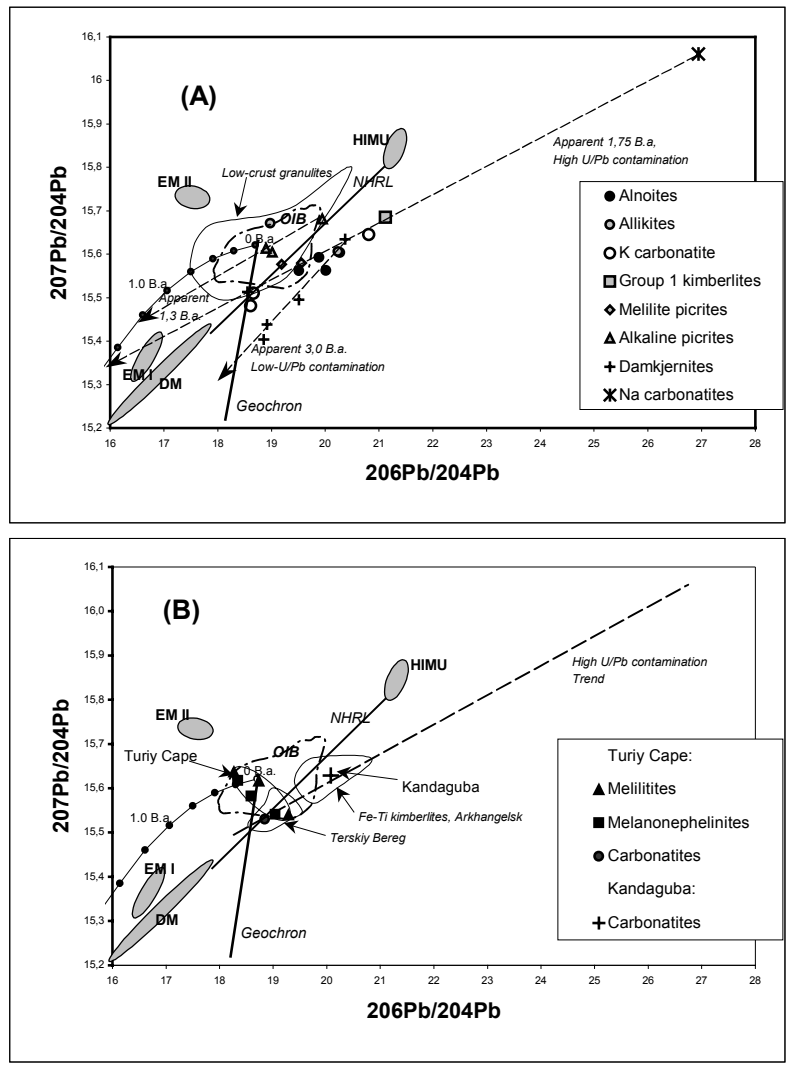

Figure 6 (A, B). Present day $\mathrm{Pb}-\mathrm{Pb}$ isotope variation of Early and Late Devonian Niva rocks (A); Late Devonian Turiy and Kandaguba rocks (B).

\section{CONCLUSION}

Thus $\mathrm{Sr}-\mathrm{Nd}-\mathrm{Pb}$ isotopic and geochemical compositions indicate that the south Kola dike swarms were formed as a result of mixing of the depleted OIB source with material from three other isotopic reservoirs: the Archaean lower crust (LC), Early-Middle Proterozoic $\mathrm{U} / \mathrm{Pb}$ enriched mantle (HIMU) and Middle Proterozoic $\mathrm{U} / \mathrm{Pb}$ depleted mantle (SCLM*). Four types of mixing process can be recognized: (1) HIMU/OIB (most Early and Late Devonian Niva rocks); (2) SCLM*/HIMU/OIB (Late Devonian Niva alkaline picrites and cpx-melilitites from the Terskiy Bereg); (3) LC/HIMU/OIB (Later Devonian Niva damkjernites); (4) only OIB (Late Devonian melilitites, nephelinites and carbonatites from the Turiy Cape). A significant contribution of the OIB-mantle reservoir with the following isotopic characteristics: $\varepsilon_{\mathrm{Sr}}=-5 ; \quad \varepsilon_{\mathrm{Nd}}=+5$; ${ }^{206} \mathrm{~Pb} /{ }^{204} \mathrm{~Pb}=18.8 ;{ }^{207} \mathrm{~Pb} /{ }^{204} \mathrm{~Pb}=15.7 ; \quad{ }^{208} \mathrm{~Pb} /{ }^{204} \mathrm{~Pb}=38.7$, can be observed in all dikes from Kandalaksha, as well as in the Devonian kimberlites of Kola-Arkhangelsk region, the alkaline rocks of central Kola and the carbonatites of northern Karelia (Kramm, 1993; Zaitsev\&Bell, 1995; Arzamastsev et al, 1998; Verhulst, et al, 2000). The authors have interpreted this dominant contribution of OIB mantle reservoir as supporting evidence for an early Devonian mantle plume, which impacted the base of the lithosphere in northwest Russia and initiated widespread magmatism.

Formation of the Late Devonian dikes of the Turiy Cape due to the influence of the mantle plume indicates the maximum thinning and extension of the lithosphere in this area. The absence of the HIMU component in the isotopic-geochemical composition of Turiy Cape dikes indicates that this component was inhomogeneously distributed in the Kola mantle and was not related to the Devonian mantle plume. Unlike the HIMU component of St. Helena, this component is characterised by an abnormal $\mathrm{Pb}$-isotope composition $\left({ }^{206} \mathrm{~Pb} /{ }^{204} \mathrm{~Pb}=26.9 ;{ }^{207} \mathrm{~Pb} /{ }^{204} \mathrm{~Pb}=16.06 ;{ }^{208} \mathrm{~Pb} /{ }^{204} \mathrm{~Pb}=39.4-\right.$ 41.4). Such a composition may originate from an isolated mantle reservoir with a variable $\mathrm{Th} / \mathrm{U}$ ratio, and with an unusually high $\mathrm{U} / \mathrm{Pb}$ ratio exceeding that in the St.Helena OIB-source. Formation of such a reservoir with an abnormal HIMU component could be related to Early Proterozoic subduction (1.9-2.0 B.a.) of the Belomorian belt, which resulted in the remains of the ancient subducted oceanic crust being buried under the lithosphere plate. As a result of post-subduction cooling starting at 1.75 B.a the mixture of asthenosphere and subducted crust was isolated from the asthenosphere. Later Middle Proterozoic rifting probably remobilised parts of the deepest lithosphere layer that comprised the abnormal HIMU component resulting in formation of a new subcontinental lithospheric mantle (SCLM*) depleted in $U$ and slightly enriched in Rb and LREE. The lithosphere above the HIMU component layer was characterised by an EM-I signature. Formation of such a lithospheric component was perhaps related to ancient (2.2 B.a.) metasomatism of depleted lithosphere mantle. This metasomatic event may be correlated with Early Proterozoic extension of the Kola- craton. The Devonian plume-lithosphere interaction in the Arkhangelsk region expanded within the EM-1 and HIMU lithospheric layers comprising diamondiferous mantle regions, whereas in south Kola the interaction was limited only to the deepest and partly remobilised HIMU lithospheric layer.

\section{REFERENCE}

Andreev, S.I., Miller, Yu.V., 1999. A longitudinal profile of the Belomorian mobile belt. Otechestvennaya geologia, 2, 46-50 (in Russian).

Arzamastsev, A.A., Arzamastseva, L.A., Belyatskii, B.V., 1998. Alkaline Volcanism of the Initial Phase 
of Paleozoic Tectono-Magmatic Reactivation in Notheastern Fennoscandia: Geochemical Features and Petrologic Consequences. Petrologiya, 6, 316-336 (in Russian).

Balagansky, V.V., Glaznev, V.N., Osipenko, L.G., 1998. The Early Proterozoic Evolution of the Northern Baltic Shield: A terrain Analysis. Geotectonica, 2, 16-28 (in Russian).

Beard, A.D., Downes, H., Vetrin, V.R., Kempton, P.D., Maluski, H., 1996. Petrogenesis of Devonian lamprophyre and carbonatite minor intrusions, Kandalaksha Gulf (Kola Peninsula, Russia). Lithos, 39, 93-119.

Beard, A.D., Downes, H., Hegner, E., Sablukov, S.M., Vetrin, V.R. Balogh. K., 1998. Mineralogy and geochemistry of Devonian ultramafic minor intrusions of the southern Kola peninsula, Russia: implications for the petrogenesis of kimberlites and melilitites. Contrib Mineral Petrol, 130, 288-303.

Beard, A.D., Downes, H., Hegner, E., Sablukov, S.M., 2000. Geochemistry and mineralogy of kimberlites from the Arkhangelsk Region, NW Russia: evidence for transitional kimberlite magma types. Lithos, 51, 47-72.

Bibikova,E.V., Skiold, T, Bogdanova, S.V., 1996. Age and geodynamic aspect of the oldest rocks in the Precambrian Belomorian Belt of the Baltic (Fennoscandian) Shield. In: Precambrian Crustal Evolution in the North Atlantic Region; Geological Society Special Publication, 112, 55-67.

Bulakh, A.G., Ivannikov, V.V. (1984) Problems of mineralogy and petrology of carbonatites. Leningrad, Leningrad state University, (in Russian).

Claesson, S., Vetrin, V., Bayanova,T., Downes, H., 2000. U$\mathrm{Pb}$ zircon ages from a Devonian carbonatite dyke, Kola peninsula, Russia: a record of geological evolution from the Archaean to the Paleozoic. Lithos, 51, 95-108.

Kalinkin, M.M., Arzamastsev, A.A., Polyakov, I.V., 1993. Kimberlites and Related rocks of the Kola Region. Petrologiaya,. 2, 205-214 (in Russian).

Kramm, U. (1993) Mantle components from the Kola Alkaline Province, Russia and Finland: a NdSr study. Eur. Jour. Mineral., 5, 985-989

Mahotkin, I.L., Zhuravlev, D.Z., Sablukov, S.M., Zherdev, P.Yu, Thompson, R.N., Gibson, S.A., 1997. The plume-lithospheric interaction as a geodynamic model of the Arkhangelsk diamondiferous province. Dokl. Akad. Nauk. Rus.,353 (2), 238-242 (in Russian).

Mahotkin, I.L., Gibson, S.A. Thompson, R.N., Zhuravlev, D.Z., Zherdev, P.U., 2000. Late Devonian diamondiferous kimberlite and alkaline picrite (Proto-Kimberlite?) magmatism in the Arkhangelsk Region, NW Russia. Journal Petrology. 41, 201-227.

Ivannikov, V.V., Rukhlov, A.S., 1996. Dike series of Kandalaksha graben: petrographic nomencla- ture and genetic systematic. Vestnik St. Petersburg University, 2, 128-137 (in Russian).

Zaitsev, A., Bell, K., 1995. Sr and Nd isotope data of apatite, calcite and dolomite as indicators of source, and the relations of phoscorites and carbonatites from the Kovdor massif, Kola peninsula, Russia. Contrib. Mineral. Petrol, 121, 324-335.

Verhulst, A., Balaganskaya, E., Kirnarskiy,Y., Demaiffe, D., 2000. Petrological and geochemical (trace elements and Sr-Nd isotopes) characteristics of the Paleozoic Kovdor ultramafic, alkaline and carbonatite intrusion (Kola Peninsula, NW Russia). Lithos, 5, 1-25.

Contact: IL Mahotkin, Chayanova Street 7, Moscow,125047, Russia, E-mail: imahotkin@debeers.ru 